Walisongo Law Review (Walrev), Vol 2 No. 1 (2020)

DOI: 10.21580/Walrev/2020.2.1.5506

Copyright ( 92020 Walisongo Law Review (Walrev)

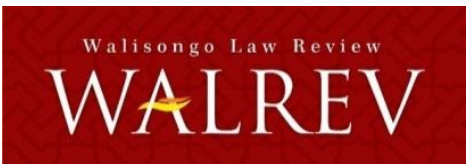

\title{
Presumption of Innocence Against Criminal Offenders in the Police: A Critical Study
}

\author{
Oktavia Wulandari' ${ }^{1}$, Ali Imron², Briliyan Ernawati ${ }^{3}$, Nazar \\ Nurdin 4 \\ Afiliasi: Universitas Islam Negeri (UIN) Walisongo, Semarang \\ Email: oktavia@gmail.com ${ }^{1}$; ali.imron@walisongo.ac.id ${ }^{2}$; \\ briliyanerna@yahoo.co.id3; nazar@walisongo.ac.id4
}

\begin{abstract}
The purpose of this paper is to conduct a critical study of the application of the presumption of innocence to the perpetrators of criminal acts (suspects) investigated by the police. Implementation of the principle is important to study because the suspect must not be considered guilty before the criminal act is proven. A review of this case was carried out at the Kendal Police Department in mid-2019-2020. Writing texts are written with a normative-empirical approach. The non-doctrinal approach was chosen because it can clearly examine the application of the principle of presumption of innocence in more depth. Therefore, the author considers it necessary to carefully examine the application of these principles in the process of law enforcement at the police level. The results showed that the application of the principle of presumption of innocence in the Kendal Police Department was not optimal, because some of its applications were colored by threats and acts of violence. The suboptimal application of this principle is
\end{abstract}


influenced by various factors, including the lack of legal knowledge of suspects and threats and acts of violence that are not reported. As we know the presumption of innocence is a fundamental principle in the criminal justice system, where a person must be positioned innocent before his guilt is proven in an honest and open trial.

Tujuan penulisan ini adalah untuk melakukan telaah kritis atas penerapan asas praduga tak bersalah kepada pelaku tindak pidana (tersangka) yang diselidiki oleh pihak kepolisian. Implementasi atas asas tersebut penting dikaji lantaran tersangka tidak boleh dianggap bersalah sebelum perbuatan pidananya dibuktikan. Telaah atas kasus ini dilaksanakan di Kepolisian Resor Kendal pada medio 20192020. Naskah penulisan ditulis dengan pendekatan normatifempiris. Pendekatan non-doktrinal dipilih karena dapat menelaah secara jelas atas penerapan asas presumption of innocence ini secara lebih mendalam. Oleh karena itu, penulis memandang perlu menelaah dengan seksama penerapan asas tersebut dalam proses penegakan hukumnya di tingkat kepolisian. Hasil penelitian menunjukkan, penerapan asas praduga tak bersalah di Kepolisian Resor Kendal belum optimal, karena sebagian penerapannya diwarnai dengan ancaman dan tindak kekerasan. Belum optimalnya penerapan asas ini dipengaruhi oleh berbagai faktor, diantaranya yaitu minimnya pengetahuan hukum para tersangka dan adanya ancaman beserta tindak kekerasan yang tidak dilaporkan. Seperti diketahui presumption of innocence adalah asas-asas fundamental dalam sistem peradilan pidana, dimana seorang harus diposisikan tidak bersalah sebelum kesalahannya terbukti di dalam sebuah peradilan yang jujur dan terbuka.

Keywords: the presumption of innocence; suspect; police; the threat of violence.

\section{Introduction}

Indonesia is a state of law. An independent state which exercises its governmental authority based on the law (Pemerintah RI 1945:Article 3). In running the government, the state must not carry out activities based on power but based on laws that promote human 
rights, fulfill all the rights of citizens. According to L. M. Friedman, the law is a system that plays a role in society if the implementation is equipped with instruments (Hatta 2009:12). Law as a system consists of a combination of sub-systems. According to Friedman, these subsystems that form are the structure, culture, and substance. These three elements run the legal system according to its tracks.

In a state of law, law enforcement must also pay attention to aspects of justice, expediency, and certainty (Hatta 2009:12). The purpose of the law is to create social order (legal order). Compliance with absolute social order as a precondition for the formation of an orderly society. Nevertheless, aspects of justice in the rule of law are not necessarily ruled out. Justice as a basic principle must be accompanied by the principle of equality before the law and the principle of presumption of innocence (Rukmini 2003:64).

Over time, the development of criminal acts tends to increase and varied. Community members themselves who violate legal norms. However, a person who violates still has the right to defend himself from all charges. This right to defend oneself in the justice system is called presumption of innocence (Rukmini 2003:65). Several laws and regulations govern this principle, including: article 3 letter $\mathrm{c}$ of the Criminal Procedure Code (KUHAP) 1, Article 8 paragraph 1 of Law Number 48 of 2009 concerning Judicial Power 2, Article 18 paragraph 1 of Law Number 391999 concerning Human Rights3 (RI 1999).

Perpetrators of crimes must be placed in the position of people who have a sense of respect (Harahap 2006:34). They should be respected as subjects, as examined. A criminal should not be 'branded' guilty until a court decision that has permanent powers. Presumption of innocence is an inherent right for a suspect as a human being. This right is the same as the right to get married, participate in elections, and so on (online law, 2019).

The existence of this alleged act against the law then the law enforcers conduct an investigation, namely efforts to find and find an event that is suspected to be a criminal offense. After the alleged 
crime was discovered, it was then upgraded to an investigation. After being investigated, a criminal event that was declared complete was then transferred to the prosecution stage. If the evidence supporting this criminal finding is already strong then it is submitted to the court for trial (Bakhri 2014:141). In this process, law enforcement officials are permitted to make forced efforts, including: arrest; detention; search; and confiscation (Pemerintah RI 1981). But it was confirmed in the Criminal Procedure Code, the position of the suspect was as a subject. Because of the subject, every examination must prioritize human dignity. As a subject, the suspect must not be treated harshly, even with activities in the form of forced efforts.

From the application of this principle, the author found some interesting things. The findings of the author, many criminal offenders do not get good treatment as there is in the guarantee of the principle of presumption of innocence. The data source that we obtained, the application of the principle was not heeded in the process at the police level. It was stated that almost all of the perpetrators of criminal acts were treated unfairly, and were not treated as free human beings. Naturally, the suspect still gets his rights even though he is strongly suspected of committing criminal acts. The constitution guarantees the basic rights of every citizen. State officials are not allowed to act arbitrarily to their citizens. If the authorities fulfill the suspect's rights, it means that the law in Indonesia has separated itself from colonial laws (Agustian 2009:16).

Based on the above provisions, this paper explores further about the application of the presumption of innocence in the criminal justice process, particularly at the level of investigation and investigation. The locus of research was conducted at the Kendal Police Department. From this formulation, there are two basic questions: first, how is the pattern of applying the principle of presumption of innocence to the suspect?; second, how is law enforcement against the practice of deviating the principle of presumption of innocence at the police level?

This writing uses a normative-empirical approach because the study is the implementation of legal provisions that apply to in 
concreto legal events in society (Abdulkadir 2004:52). In accordance with this method, the first study was conducted by examining norms, principles whether contained in the primary or secondary material. To strengthen the writing, field research was also carried out, specifically focusing on the implementation of the presumption of innocence to the suspects. This writing is a type of non-doctrinal legal research (Wignjosoebroto 2006:73). This type was chosen because they want to knot the law is implemented, including the enforcement process (Baro 2016:1). After the data is collected, data analysis is carried out using a qualitative approach (Ali 2014:106) of available data.

\section{Presumption of Innocence in the Criminal Justice System}

Presumption of innocence has been known since the 11th century. This principle is the essence of the realization of the protection of human rights. Rukmini explains, this principle means that a person suspected of committing a crime is considered innocent until his mistakes are proven in court (Rukmini 2003:244). A convicted if, in the process, there are facts that support the following ballast circumstances. This principle is clearly regulated by the justice system in Indonesia. If the application of the principle is considered, a person is entitled to obtain compensation (Husin 2016:82).

The principle of presumption of innocence is a manifestation of modern justice. He took over the role of revenge through state institutions. All criminal violations in the community are resolved through applicable procedures (Tahir 2010:7). Presumption of innocence is a principle of protecting the rights of citizens in a fair process. Rights protection includes: protection from arbitrary acts; protection from guilty stigma; protection from closed justice; and protection of the right to self-defense. If violated, a person has the right to receive compensation and rehabilitation (Rukmini 2003:172).

The purpose of applying the presumption of innocence is to provide guidelines for promoting the principle of the accumulator, placing the position of the offender as the subject (Nurhasan 
2017:208). In addition, this principle encourages the recognition of certain rights as stipulated in the Criminal Procedure Code. The impact of applying this principle in the process is evident. A criminal event that is revealed by a legal officer must really be proven guilty. The right of proof is inherent in law enforcement, and the perpetrator cannot be forced to admit the deeds committed. In other words, this principle is like the explanatory line governing the behavior of law enforcers. In addition to this principle, the provisions of the principle of equality before the law also apply (together before the law). Both principles are fundamental principles that are based on human rights.

While the criminal justice system or criminal justice system is a mechanism of action in overcoming crime based on a system. This system is the authority to uphold the law or the power of the judiciary, which is divided into four: power in the investigation; citation; trial and execution, or execution. Each power is exercised by a separate institution. The Criminal Procedure Code regulates the detailed implementation of this judicial power in punishing and establishing a conviction. The justice system is a unified system, from structural, substantial, and cultural systems. This system can be called a combination of administrative, normative, and social systems. In its implementation, all must be carried out honestly and fairly.

In processing criminal events, law enforcement officers at the level of investigation and investigation have an important role, because they are an integral part of the criminal system. The authorities must be detailed in accusing a person suspected of committing a criminal act (the suspect). A suspect5, when processed during a preliminary hearing, must be placed fairly before the law. The legal apparatus is not justified in justifying a person "because of his actions and circumstances." If you use the term, as if the investigator knows the actions and circumstances of the suspect, even though evidence must be sought first (Hamzah 2008:67). In determining a suspect, the authorities must pocket at least one piece of evidence, both witness statements, expert statements, and letters. If you get evidence, a legitimate person is determined as the person who is suspected of committing a crime. 
Although it has become a suspect, a person still has his rights because of the principles of the presumption of innocence and equality before the law. The principle provides an illustration, a person suspected, suspected, or charged with a criminal offense is not 'branded' guilty before being tried. The inherent rights include: obtaining an examination and submitting it to the public prosecutor; submitted to the court for trial; obtain information on what actions were alleged during the examination; obtain information about the actions committed and prepare objections; provide information freely both when investigated, prosecuted and in court hearings; get translator assistance; get legal assistance; elect legal counsel; get a doctor's examination; notify criminal information to the family; receive a visit; sending and receiving letters; get a trial that is open to the public; submit witnesses; not burdened with proof of obligation; and obtain compensation and rehabilitation if the process is not in accordance or contrary to law (Pemerintah RI 1981:Article 58-60). These inherent rights are part of legal protection to support the application of the principle of presumption of innocence in the criminal justice system.

\section{Application of Presumption of Innocence in the police}

The application of the presumption of innocence in the criminal justice system proves that the Indonesian state is based on law. Speaking of application is the same as discussing this principle in the justice system in Indonesia, ranging from investigations to prison. However, the focus of this paper is at the level of investigation and investigation carried out by the police. The application of this principle is not maximized not because of the rules, but in the culture of law enforcement.

The application of the principle in the police, especially in the Kendal Police Department, the location of the study, do not ideally reflect the application of this fundamental principle. The application of the principle is not yet fully in accordance with the applicable laws and regulations, especially in the phrase 'considered guilty'. As a rule of law that uses this principle, a person suspected of committing a crime is not treated as a guilty person, even if that person is arrested 
and is subjected to a physical imprisonment process. All must respect the human rights inherent in an independent person (Seno Adji 1981:251). The principle of presumption of innocence is the main principle in the criminal justice system that is open and fair. This principle provides protection for a person who is allowed to act arbitrarily. This principle provides flexibility so that a person suspected of being able to defend himself (Reskodiputro 1994:36).

In the process in the police, the examination of a person suspected through several patterns. If a person is caught in the act of allegedly committing a crime, an investigation is immediately conducted. If not, then the handling process is through a complaint or reporting booth. In this second pattern, the officer cannot begin with an investigation (determining the suspect), but first starts from the search for a criminal event or an investigation (Interview with Cristian, 2020).

If there is a report or complaint, the officer will verify the report by clarifying it to the reporting party. After all classes, then proceed with the administrative process or filing for the sake of searching for a criminal event or investigation. In this process, or after administration is done, will be continued with the summons of the reported by sending a summons to be asked for information.

After this process, or when all information obtained from the investigation process is declared complete or meets the requirements for a criminal act, it is not immediately brought into the criminal domain. The process starts with mediation, or is settled amicably or chooses to proceed into legal channels. If mediation fails, it means the reporting case continues to the legal desk. It is in this process that the police conduct a case title process. In the case title, all unit heads are gathered, accompanied by supervisory police to ensure that reporting can be raised at the investigation level or not. After the case title, the case is raised to the stage of an investigation, or the determination of a person suspected of committing a crime or a suspect (Interview with Cristian, 2020). 
Related to the application of the principle of presumption of innocence answered by police officers in accordance with the provisions. That was based on the results of the author's interview with several members of the Kendal Police Department. The officer has given all the inherent rights to the suspect, starting the arrest which is not accompanied by violence or other actions until there is a court decision. Arrests by violence are only carried out when the suspect is resisting (Interview with Pamungkas, 2019). The process of selecting a legal advisor is also given freely, whether to choose by yourself or to choose the legal advisor provided. In a criminal act that exceeds the threat of a 5-year sentence must be accompanied by a legal advisor. Legal advisors accompany to ensure the rights of the suspect in the examination are not violated. If a violation is felt, the suspect or legal advisor has the right to report to the profession and security (propam) in the police department. He emphasized that investigators do work professionally, and have good ethics (Interview with Pamungkas, 2019).

To speed up the handling of the case, a person suspected of being allowed to be detained for 20 days. If there are still difficulties, it is also given a lengthy 40 days to collect all the preliminary evidence. If it is finished, submit it to the public prosecutor until it is declared complete or P21. Specifically, Pamungkas (2019) said that investigators fully guarantee the rights of suspects. The action was taken by the police guarantees operational examination standards, namely preparing competent investigators and assistant investigators; the existence of an investigator supervisor (wasdik) whose duty is to oversee the discipline and performance of the investigator and the assistant investigator in the investigation process; and involving the profession and security (propam) in its supervision. Involvement of propam is done so that when there is a deviation of the principle of the presumption of innocence of the suspect, the propam can immediately evaluate the relevant officer, and the case will continue.

Sources obtained from the Kendal Police Department also on average said the application of this principle had been fully carried 
out. According to Christian (2020), the application of the principle of presumption of innocence in the level of investigation and investigation is always done to a reported or suspected criminal. "We investigators have techniques in investigation and suspect rights, we always fulfill them. Although sometimes the question from the investigator is a little rude, it is so that the suspect wants to admit what he has done. Sometimes, we do interviews for a long time, but suspects sometimes don't want to confess even though we have already obtained evidence, "(Interview with Cristian, 2020).

The application of this principle is said to have been carried out properly by investigators. However, he cannot guarantee the application of this principle to other fields, for example when a person is in temporary detention. If there are officers who perform actions that are considered unpleasant, it is not included in the authority of the investigator. Officers do not deny in emergencies, for example, a crowd, sometimes officers have difficulty supervising a person who is suspected, then some actions are considered as rude acts. This was thus triggered by differences in understanding between officers in respecting the suspect's rights. Thus, he considers the application of this principle to have gone well, and only a few parts are lacking. If the suspects feel treated harshly, then they are free to report to the propam so that the officer in charge of guarding can be evaluated (Interview with Cristian, 2020). But Cristian refused to explain how the handling procedure.

As with the previous information, Cristian said if the application of the principle goes well. Suspects suspected of committing crimes in which a criminal threat is more than five years must be accompanied by legal counsel. The police require this if the suspect does not want to be appointed a legal advisor to provide assistance. Legal counsel in the position of accompanying the suspect so that inherent rights can be obtained properly, as well as ensuring there are no procedural errors in the process.

While the source of information in the propam section strengthens the opinion of the investigator. Our source said that the application of the principle of presumption of innocence is something that must be 
fulfilled when investigating or investigating. According to Supriyanto (2020), the guilty stamp has no right to be pinned before a court ruling. The inherent rights must be fulfilled by the officer. If indeed in the process there is a violation of this principle, then his party, propam, will conduct internal handling. This internal handling has entered into a professional code of ethics for members of the Indonesian police force. More clearly, the handling of the code of ethics is regulated in Regulation of the Chief of Police (Perkap) No. 14 of 2011 concerning the Republic of Indonesia National Police Code of Ethics and Regulation of the National Police Chief (Perkap) No. 19 of 2012 concerning the Organizational Structure and Working Procedure of the Republic of Indonesia National Police Code of Ethics Commission.

To ensure the fulfillment of the rights of the suspect to avoid the practice of irregularities, the police conduct surveillance in the process of examining suspects. Supervision is carried out during the investigation process by investigators overseen by wasdik (investigator supervisors). Because of the clearance process, it was stated that so far there have been no bad reports regarding violations of this principle to the propam party. "The practice of deviations or violations of the principle of presumption of innocence is not justified. If a police officer is proven to have committed a violation against a suspect in Kendal Police Department, the officer or apparatus must be processed through a hearing of the police profession code of ethics and the imposition of sanctions that have been regulated in Regulation of the Chief of Police No. 14 of 2011 concerning Polri's Professional Ethics Code."

In this regulation especially article 20 it is stated that every member of the Indonesian National Police suspected of violating the obligations and/or prohibitions was declared a violator after being examined and received a decision through the KEPP Session. The sanctions for violating KEPP against the perpetrators in Article 20 are in the form of violators behavior is declared a despicable act; the offender's obligation to apologize verbally before the KKEP session and/or in writing to the National Police leadership and the injured 
party; the obligation of the offender to follow the mental development of personality, psychiatric, religious and professional knowledge, at least one (1) week and a maximum of one month; be transferred to a different position which is a Demotion for at least one year; transferred to a different function which is Demotion for at least one year; transferred to a different area which is Demotion for at least one year; and/or dismissal not respectfully (PTDH) as a member of the National Police (Polri, 2011).

From information from various sources, it can be concluded that law enforcement against deviations or violations of the principle of the presumption of innocent will be processed internally by the police, in this case, Propam. Internal evaluation in question is the police code of ethics session if there are reports of irregularities on the presumption of innocence related to the discipline or behavior of officers and the code of ethics or performance of officers. If there is sufficient evidence that there is a criminal offense against the suspect, then the officer who committed the violation can be prosecuted according to criminal law. When there is not enough evidence, it can be processed at the hearing of the national police profession code of ethics and then subject to administrative sanctions as mentioned above.

Unlike the police, an ex-convict who was processed by the court complained about the improper treatment received during the process at the police. He considered the application of the principle of presumption of innocence is not intact, because it is still accompanied by threats and acts of violence. The author's source at the initials Kendal DP claimed to have been treated rudely by officers. Our source acknowledged, during detention for 40 days when the investigation had received work for push-ups to find harsh treatment. Our other source, initial R, was unable to share his experience because during the interview awaited officers. $\mathrm{R}$ was not free to say what he was going through. Nevertheless, he found in the process of interviewing $R$, he was not accompanied by a lawyer. It is possible because criminal acts are considered a mild category, namely the theft of cigarettes, where the threat of punishment is less than five years. 
The author also gained empirical experience from ex-convicts who had dealt with the police. Our sources are the initials $\mathrm{H}$ detained in 2013, the initials SA detained in 2012, the initials of GS in 2016, and the initials of AR in 2015. Different from police statements, exconvicts explained in such detail that the average who had been detained at the police station was treated arbitrarily. Some are treated roughly by being hit in several parts of the body. Our source $\mathrm{H}$ has also felt a punch from the officer in the face (Interview with H, 2019). Our source explained that the harsh treatment was not obtained from the time of the investigation, but from the prison guards who were on average young. "What is often beaten is usually the same thief. At that time I saw that there were still many who were 'beat up' (interview with $H$, 2019).

In contrast to $\mathrm{H}, \mathrm{SA}$ who was detained for a crime of gambling in 2012 did not feel excessive acts. He and other prisoners were tricked with standing for a long time, some others walked by crouching. The sentence was obtained because someone was found smoking in prison (Interview with SA, 2020). In contrast to SA, the GS who was caught red-handed stealing motorcycles by residents were then picked up by the police to be taken to the police. GS claims to have been treated harshly, but not from officers, but rather was treated harshly from fellow prisoners (Interview with GS, 2020). Our other source, AR, 2015 experienced a different treatment. A person arrested for gambling allegations in 2015 was forced to admit that he had committed a criminal offense. He dismissed the accusation, that he went to the location of the chicken noodle shop (gambling location) to look for food, not to play gambling. AR claimed that he had been detained all night and was being threatened and abused because he was hit by a rattan in the back. He was treated because he was forced to admit to gambling. At that time, in the process of examining officers, he claimed not to be accompanied by a legal advisor. (Interview with AR, 2020).

To obtain information about the application of this principle in its entirety, the author also requests a legal advisory attack, in this case from the Putra Nusantara Legal Aid Institute. It was explained from 
this $\mathrm{LBH}$, that his party had never provided assistance to suspects, not in general crimes (PIDs) who had a mild sentence. The LBH was only asked to assist the suspects in specific criminal acts such as narcotics because they entered with the threat of high penalties (Interview Noviandry, 2020). He said the principle of presumption of innocence is not completely intact because of the lack of assistance from legal counsel. Regarding harsh treatment, another LBH representative, Kristianto explained, violations of the principle are common, but the practice is difficult to uncover. Because of the difficulty of disclosure, he even said that during the accompaniment of a general criminal offense, his party had never received a report from a client about acts of violence or threats of violence. But he did not deny that if the suspects were more likely to remain silent save their experiences rather than report the incident to another party (Interview with Kritanto, 2020).

\section{Enforcement of the Deviation of the Presumption of Innocence}

Deviations from the principle of the presumption of innocence are often the case. Deviation itself is an individual or joint act carried out outside of the supposed rules. The author found a number of irregularities in the examination process at the police level which is a fragment of the criminal justice system. At this level, especially in the case of investigations, the suspects are in the spotlight because they are prone to misuse of the principle.

Several sources that the author met mentioned, law enforcement at that level still leaves some behavior that is not supposed to be done. This then becomes interesting because the target victims are small people who commit violations of general crime. On average those who are treated harshly are those who do not recognize the criminal acts committed, or do not comply with the wishes of the authorities. From the data collected, bad practices still occur at the police level, and that was done not only by the authorities but by other prisoners. Violence in the process of handling crimes should not be legally justified because it guarantees the rights of suspects. 
However, there are still sources that mention a number of officers who violate this principle even though it is guaranteed by the constitution. Based on research, acts of violence experienced by suspects, or ex-convicts who were previously detained, whether committed by officials or other parties show deviant actions. These actions can be categorized as violence or torture that physically and psychologically affects the suspect. According to Pamungkas (2020), all forms of irregularities should be reported so that the officer in charge can be evaluated by the propam or provos division, while the case is continued with other officers. This was also corroborated by Supriyanto (2019), who said the principle of the presumption of innocence is the principle attached to the suspect and should not be violated by anyone before there is a decision.

Therefore, it is not justified if the rights attached to one are violated by someone else, especially taken by the officer. When violence occurs, propam should be able to act without having to wait for reporting. Supriyanto continued, that the application of the principle of presumption of innocence must be put forward. According to the author, law enforcement on the practice of deviations from this principle is still less efficient, because there is still recognition of arbitrary actions taken by the authorities. That still happens often because of weak supervision.

The monitoring police cannot act when there are no reports. Therefore, propam cannot act against members suspected of committing the deviation. Propam should be able to guarantee that the officers in charge do not exceed the limits so that the rights of the suspect are not violated. The author considers the enforcement of the principle of the presumption of innocence in the police is still not effective, because not all officers from various units are responsible for the tasks and authorities are given by the law. Although the authorities explained that they had never violated this principle, the average suspect or former inmate admitted or saw acts of violence still occurring frequently. If there is still violence against the suspect, it means that there is still a deviation from the presumption of innocence. 
Of course, this act of violence harms the law enforcement process in Indonesia, which is supposed to carry out its duties and responsibilities as well as its authority to carry out the law in accordance with its corridors for the achievement of justice. Law is the rule to govern society. Therefore, the law must be able to follow the rhythm of community development, even the law must be able to direct and encourage the development of society more precisely and in a controlled manner. One factor influencing law enforcement is the existence of public legal awareness. This legal awareness plays an important role in law enforcement in the police. The weaker the level of public awareness, the weaker the compliance of the law. Conversely, the stronger the legal awareness, the stronger the legal compliance factor.

Various violations of the law that occurred were the impact of the lack of legal awareness in society. So that the process of development and effectiveness of law can be felt directly by the community itself. Public legal awareness is a series of processes that occur step by step. The more thought of a society develops, the higher its legal awareness.

Legal awareness starts from people's thinking to create a peaceful and safe life. That can be done well if the community has a high level of legal awareness. Public legal awareness is very influential in legal compliance, both directly and indirectly. In developed societies, people who obey the law because they realize that the need for law and law have a good purpose to regulate society properly, correctly, and fairly.

In contrast, in traditional societies, community legal awareness has an indirect effect on legal compliance. In this case, they obey the law, not because of their direct belief that the law is good, or because they really need the law, but they obey the law more because it is requested, even forced by its leaders.

Likewise, community legal awareness in the Kendal jurisdiction, which can be said to be minimal. Geographical factors where people live in rural areas cause a lack of knowledge about the law and the 
impact of lack of community legal awareness. This is proven when there is an acknowledgment of the violence experienced but the community prefers to be silent and accept the reality of the matter, even though their human rights are violated. May the proverbial law blunt upward, sharp below is still proven if it is not accompanied by qualified awareness. The laws and regulations are used as accessories in law enforcement. Supposedly, law enforcement can reflect the feelings or values of justice that live in their communities. Thus it can be concluded, that enforcement at the police level in its efforts to protect the principle of the presumption of innocence still often deviates from what it should.

\section{Critical Study}

Based on previous data, the author is again concerned about the practice of violation of this principle, because of arbitrary actions, whether in the form of coercion to admit a criminal event or with threats and acts of violence to suspects or ex-convicts who are the source of research. The author examines the understanding of this principle by officers not evenly distributed. There are officers in certain units who are well-versed and provide rights for suspects, but in other parts, for one reason or another, to commit violence because they are considered to have committed a crime. This is certainly not justified for any reason before the court decides its mistakes to have permanent legal force.

Other deviations found were acts of violence because there was no assistance from legal counsel. A person suspected of having the right to be accompanied by a legal advisor should not have their rights violated. However, one research source said that he was given abusive treatment for not recognizing the deeds. In addition, he also could not defend the argument because it was not accompanied by legal counsel. In accordance with regulations, the process of examining suspects should always pay attention to the rights of suspects as stipulated in KUHAP Article 52, which states that "The suspect/defendant has the right to provide information freely both to the investigator at the level of investigation and to the judge in the 
examination process at the court hearing. However, in practice, these rules have not been fully explored.

Another deviation was found, namely the existence of extortion. Our sources report that acts of violence will be stopped if in practice prisoners give tribute to officers. Prisoners who are more economically established will be freer from the shadow of violence, while prisoners who are economically weak will experience the threat of violence. But information like this needs more concrete evidence, and not just empirical experience so as not to cause libel to law enforcement. If this often happens, it is very unfortunate if something like this is still considered a normal thing.

Another finding is the disagreement of knowledge about the application of the principle of presumption of innocence from the results of interviews and observations in the field. Police sources say the application of the presumption of innocence is in accordance with the law. On the other hand, the principle was harmed by police officers in other units. This is triggered by the number of tasks and functions in each unit so that the understanding of the principle of presumption of innocence is still not optimal. Although in the process of checking and investigating the application of this principle, the priority is always prioritized, but on the other hand, it is still injured by several police officers who are still carrying out acts of violence. This proves that the application of the principle is still not fully optimized.

Other findings from interviews with police sources said that each suspect was accompanied by an advocate. But in its application, the writer did not find any assistance or legal assistance by advocates to the suspect. It can be said, that the legislation governing the presumption of innocence is only a formality, but it is not implemented as it should. Quoting Lawrence Friedman, the success or failure of law enforcement depends on the substance of the law, legal structure/legal institutions, and legal culture. The author feels the legal institutions mentioned by Friedman have not been optimally implemented. 


\section{Conclusion}

Based on the results of the research and discussion above, the following conclusions can be drawn. First, the application of the principle of presumption of innocence has not been optimally implemented at the police level, particularly at the Kendal Police Department. The suboptimal application of this principle is evidenced by the continued threat of violence, the absence of legal counsel for the suspects. In fact, the threat of physical violence during an investigation still colors the violation of this principle. This acknowledgment from the source empirically proved that the implementation of this principle was not yet optimal in the community.

Secondly, law enforcement against the practice of deviating the principle of presumption of innocence in the Kendal Police Department is indeed regulated under Perkap No. 14 of 2011 concerning the Code of Ethics and Perkap No. 19 of 2012 concerning the Organizational Structure and Work Procedure of the Code of Ethics Commission. In the regulation, if there is a deviation from the discipline of member performance related to the presumption of innocence, the party responsible for handling is propam, which will proceed through the code of ethics hearing. However, this enforcement is still in place because of the lack of incoming reports. $[\mathrm{w}]$

\section{Noted}

1. KUHAP item 3 letter c, namely: "Every person who is suspected, arrested, detained, prosecuted, and or before a court of law must be considered innocent until a court ruling states his guilt and obtains permanent legal force."

2. Article 8 paragraph (1) of Law No. 48 of 2009 concerning Judicial Power, which states that: "Everyone who is suspected, arrested, detained, prosecuted or confronted before a court must be presumed innocent before a court ruling states his guilt and has obtained permanent legal force." 
3. In the provisions of Article 18 paragraph (1) of Law No. 39 of 1999 concerning Human Rights, states that: "Everyone who is arrested, detained, and prosecuted because they are suspected of committing a criminal offense has the right to be presumed innocent until proven guilty in a court of law and given all legal guarantees needed for his defense, in accordance with statutory provisions"

4. Article 1 number 2 of the Criminal Procedure Code stipulates that "Investigation is a series of investigative actions in the matter and in the manner stipulated in this law to search for and collect evidence which clearly explains the criminal act and to find the suspect".

5. A suspect is a person who because of his actions or circumstances, based on preliminary evidence should be suspected as a criminal (Article 8 of Law No. 14 of 1970). A suspect is a person who due to his actions or circumstances based on preliminary evidence should be suspected as a criminal (Article 1 point 14 of the Criminal Procedure Code). "Preliminary evidence is evidence in the form of a Police Report and 1 (one) legal evidence, which is used to suspect that someone has committed a crime as a basis for arrest" (Article 1 point 21 of Perkap No. 14 of 2012). In the process, "In the examination at the level of the court investigator, the suspect or accused has the right to provide information freely to the investigator and judge" (article 52 of the Criminal Procedure Code).

\section{Reference}

Abdulkadir, Muhammad. 2004. Hukum Dan Penelitian Hukum. Bandung: Citra Aditya Bakti.

Agustian, Tomi. 2009. "Formalisasi Hukum Islam Kedalam Tata Hukum Indonesia." in Pertanggungjawaban Hukum, edited by Ali Imran. Semarang: Walisongo Pres.

Ali, Zainuddin. 2014. Metode Penelitian Hukum. Jakarta: Sinar Grafika. 
Bakhri, Syaiful. 2014. Sistem Peradilan Pidana Di Indonesia. Yogyakarta: Pustaka Pelajar.

Baro, Rachmad. 2016. Penelitian Hukum Non-Doktrinal Trend Penggunaan Metode Dan Tekhnik Penelitian Sosial Di Bidang Hukum. Yogyakarta: Deepublish.

Hamzah, Andi. 2008. Hukum Acara Pidana Indonesia. Jakarta: Sinar Grafika.

Harahap, M. Yahya. 2006. Pembahasan Permasalahan Dan Penerapan KUHAP Penyidikan Dan Penuntutan. Jakarta: Sinar Grafika.

Hatta, Moh. 2009. Beberapa Masalah Penegakan Hukum Pidana Umum Dan Pidana Khusus. Yogyakarta: Liberty.

Husin, Kadri and Budi Rizki Husin. 2016. Sistem Peradilan Pidana Di Indonesia. Jakarta: Sinar Grafika.

Interview with Cristian, 2020.

Interview with Pamungkas, 2019.

Interview with Noviandry, 2020.

Interview with Kristanto, 2020

Interview with $\mathrm{H}, 2019$.

Interveiw with SA, 2019.

Interview with R, 2019.

Interview with GS, 2019.

Interview with SA, 2019.

Nurhasan. 2017. "Keberadaan Asas Praduga Tak Bersalah Pada Proses Peradilan Pidana.” Jurnal Ilmiah 17(3).

Pemerintah RI. 1945. "Undang-Undang Dasar RI Tahun 1945.”

Pemerintah RI. 1981. "Undang-Undang Nomor 8 Tahun 1981 Tentang Kitab Undag-Undang Hukum Acara Pidana."

Pemerintah RI. 1999. "Undang-Undang RI Nomor 39 Tahun 1999 
Tentang Hak Asasi Manusia.”

Pemerintah RI. 2009. "Undang-Undang RI Nomor 48 Tahun 2009 tentang Kekuasaan Kehakiman"

Pemerintah RI. 2002. "Undang-Undang RI Nomor 2 Tahun 2002 tentang Kepolisian"

Peraturan Kepala Polri Nomor 14 Tahun 2011 tentang Kode Etik Profesi Kepolisian NegaraRepublik Indonesia

Reskodiputro, Marjono. 1994. Hak Asasi Manusia Dalam Sistem Peradilan Pidana. Pusat Pelayana Keadilan Dan Pengabdian Hukum. Jakarta: Lembaga Kriminologi UI.

Rukmini, Mien. 2003. Perlindungan HAM Melalui Asas Praduga Tidak Bersalah Dan Asas Persamaan Kedudukan Dalam Hukum Pada Sistem Peradilan Pidana Indonesia. Bandung: Alumni.

Seno Adji, Oemar. 1981. Hukum Acara Pidana Dalam Prospektif. Jakarta: Erlangga.

Tahir, Heri. 2010. Proses Hukum Yang Adil Dalam Sistem Peradilan Pidana Di Indonesia. Yogyakarta: LaksBang Pressindo.

Wignjosoebroto, Soetandyo. 2006. Hukum Paradigma, Metode Dan Masalah. Jakarta: Rajawali Press. 